\title{
Job satisfaction in Chile: geographic determinants and differences
}

\author{
Luz María Ferrada
}

\begin{abstract}
Logit, binary and multinomial models are used in this study to determine the impact of objective and perceived working conditions on workers' job satisfaction. Possible differences between job satisfaction in the Metropolitan Region and in other areas of Chile are also explored. The data used in this analysis are drawn from the first National Survey on Employment, Work, Health and Quality of Life of Workers in Chile (ENETS). Wage levels were found to have a positive impact across the board, while residence in an area other than the Metropolitan Region also had a significantly positive effect. These results were corroborated using matching techniques. The finding that subjective perceptions have a great deal of explanatory power and that their impact outweighs the influence of objective conditions may be of interest in the areas of both public policy and business administration.
\end{abstract}

\section{Keywords}

Employment, working conditions, wages, job satisfaction, measurement, surveys, econometric models, Chile

\section{JEL classification}

J280, M540, R230

\section{Author}

Luz María Ferrada is an academic with the Administrative and Economic Sciences Department of the Universidad de Los Lagos, Chile. Email: Iferrada@ulagos.cl. 


\section{Introduction}

The steady growth of Chile's gross domestic product (GDP) since the 1990s has been coupled with an expanding demand for labour and rising real wages. Data compiled by the National Institute of Statistics for 1993-2009 show increases of 1,802,064 in the number of jobs (INE, n/d) and of 1\%, on average, in annual wages over the variation in the consumer price index (CPI) (INE, n/d). A number of studies indicate, however, that these trends have not narrowed the wage gaps between different regions within the country and that job quality remains very poor. This situation raises questions as to how satisfied with their jobs Chilean workers are, what factors influence their level of job satisfaction the most and whether the results differ substantially across regions.

The international literature indicates that the way in which workers perceive their jobs has a strong impact on various aspects of their lives. This may be the most convincing justification for the large number of international studies that have been conducted in this field. Economic research in this field is quite recent, however, and especially so in Chile. Most of the research in this area has been conducted by psychologists, although studies focusing on human resource management - mainly in specific industries - have also been carried out. The chief contribution made by this study is that it deals with a subject that has been studied very little in Chile and incorporates a geographic dimension, thereby breaking new ground in this field of research in Chile.

Job satisfaction is defined in various ways in different fields of study. One generic approach that has been used in many studies involves conceptualizing it as an emotional state produced by a subject's subjective perception of his or her on-the-job experiences; this emotional state has been described as the level of well-being that a person derives from his or her job. ${ }^{1}$ It has also been defined as a reflection of the level of utility that a job provides, i.e., how well it meets a worker's needs or expectations and contributes to his or her quality of life. The determinants of job satisfaction therefore include both objective and subjective factors.

The specific objectives of this study are as follows: (i) to evaluate the impact on job satisfaction of variables associated with objective working conditions and with perceptions regarding the organization of work and the working environment; and (ii) to measure differences in job satisfaction between the Metropolitan Region and other areas of Chile.

The information used in this study is drawn from the National Survey on Employment, Work, Health and Quality of Life of Workers in Chile (ENETS) round carried out in 2009-2010, whose results cover the various regions in the country, provide information on both objective and subjective aspects of working conditions and include the data provided by responses to a number of questions about job satisfaction.

This study is composed of five sections, including this introduction. The second section provides a review of the literature on the subject. The third describes the methodology that was used, while the fourth presents the findings regarding the study's specific objectives. The fifth and final section provides an overview of the study's main conclusions.

\footnotetext{
1 See [online] http://www.insht.es/InshtWeb/Contenidos/Documentacion/TextosOnline/GuiasMonitor/Psicosociologia/l/ Ficheros/psi23.pdf.
} 


\section{The literature}

\section{Approaches}

Research on job satisfaction has been undertaken in a variety of fields, including psychology, human resource management and economics, each of which uses its own approaches and tools. Most of the studies that have focused on how different factors influence people's assessments of their own job satisfaction have taken a psychological approach, however; this field often makes use of a dual-factor model that distinguishes between extrinsic (or "hygiene") and intrinsic (or "motivation") factors. The former help to reduce dissatisfaction while the latter help to increase the level of satisfaction. Extrinsic factors shape the work environment, while intrinsic factors reflect how a person experiences the work environment (Bòria-Reverter, Crespi-Vallbona and Mascarilla-Miró, 2012); a number of economic studies on the subject have also used this model.

Economic research on job satisfaction is quite recent and has probably been associated with the epistemological development of work in this field. Early in the twentieth century, owing to the strong influence exerted by the industrial revolution, some researchers approached the subject of labour from the perspective of an activity that produces wealth (in the tradition of Adam Smith), while others viewed it in terms of the time required to make a product (in the tradition of Karl Marx) and still others visualized it as the activity that confers value on merchandise (in the tradition of David Ricardo) (Olarte, 2011). However, studies done in the 1960s and thereafter were the ones that focused on human capital (Mincer, 1958; Becker, 1964), and research findings in other fields sparked interest in the study of job satisfaction. This was when the idea that job satisfaction could be an important factor in determining productivity, growth and stability came to prominence. The research done by Freeman (1977) and those who followed in his footsteps marked a milestone in this area of inquiry.

Labour management thus became an increasingly fundamental consideration in the field of business administration. The evolving views regarding this factor are illustrated by three different approaches to the subject. First, Taylor focused on models for improving individual and collective physical effort as a means of boosting labour productivity (Chiavenato, 2006). Later, the focus shifted to analyses of organizational behaviour (Stephen and Timothy, 2013) that posit that greater motivation in the workplace and job satisfaction could lead to the achievement of corporate objectives (Herzberg, Mausner and Snyderman, 1959; Herzberg, 1962). A third ("new management") approach centres around human resources management aimed at shaping a management style that will help employers and employees to build a collaborative relationship whereby workers will shoulder responsibility for corporate objectives and will identify with those goals because they have come to share ownership of the company's core values (Narbona, 2012). This approach seeks to foster a subjective relationship with work that goes beyond the bounds set by employment contracts and engenders happiness. These authors also see a subtle form of control taking shape that prospers in an environment marked by labour flexibility and low levels of unionization (Narbona, 2012).

\section{Measuring job satisfaction}

Measuring job satisfaction is a challenging undertaking because it involves dealing with a number of elements that are difficult to evaluate. There are various possible approaches to this task, as well. The most common approach is to posit that job satisfaction can be estimated by gauging the utility of a job for the person who holds that job (Olarte, 2011) and that, therefore, a good proxy variable is the wage that the worker is willing to accept. Viewed from this standpoint, wages will be determined both 
by the supply of human capital and by the features of the work involved (higher qualifications, more personal skills, greater dedication, etc.) and the working environment (mobility within the company, unions, networking, job opportunities, etc.).

However, a job's utility for a given individual can also be evaluated on the basis of job quality and the quality of life that it affords. Much of the Latin American literature on this subject makes use of the decent work approach developed by the International Labour Organization (ILO) (ILO, 1999), which defines jobs as being of quality if, on the basis of objective factors, they are found to be jobs that are performed under conditions of freedom, equity, security and human dignity, if employees' rights are protected and if the jobs generate an adequate income and afford adequate social protection. Farné (2003) uses four yardsticks to measure the quality of working conditions: income, workday, social security and type of employment contract. Other researchers have used other approaches, however, with one example being the capability approach (Sen, 1999), which focuses on a person's functionalities, i.e., a set of personal characteristics (sex, age, level of education and others) and employment-related characteristics (type of contract, workday and others) that are associated with their job and that are converted into given capabilities (the ability to generate a high level of income or the ability to remain employed, for example). In line with this approach, people are seen as valuing those capabilities because they enable them to achieve a higher level of well-being (Sehnbruch, 2008). In other words, a given person may have a job (a good), but that good is going to be seen as being of quality only if it can be converted into a functionality that is valued by the individual concerned. Thus, the particular features of that job, in combination with the person's needs and characteristics, is what will determine the capabilities which that person can acquire by performing the job (Sehnbruch, 2012). Other authors have defined the concept of job satisfaction in ways that explicitly include subjective aspects. Reinecke and Valenzuela (2000), for example, describe it as the set of work-related factors that influence workers' level of well-being in economic, social, psychological and health-related terms (Farné, 2012).

Another group of research papers evaluate job satisfaction directly on the basis of the views expressed by jobholders who respond to survey questions which ask them to rate their degree of satisfaction or lack thereof on a set scale. A number of different questionnaires and rating scales have been designed for this purpose (Olarte, 2011).

Finally, some studies have used a multivariate analysis to gauge relative job satisfaction. In order to do so, they construct a synthetic indicator that incorporates various objective and subjective dimensions of the concept (Somarriba and others, 2010). These are the extrinsic and intrinsic factors used in the dual-factor model. They include individual traits that an employer cannot modify but that nonetheless influence a person's relative level of job satisfaction, such as demographic and residence variables, among others. Another type of factor is aspirational (e.g., self-esteem); these aspirations are never fully realized and therefore act as ongoing motivational forces (McGregor, 1981) that are related to expectations and life history.

In this study, job satisfaction is analysed on the basis of wage workers' perceptions as reported on a seven-point scale when they respond to the question: "How do you feel about your job?" (question D1h in ENETS module D). The question of how much certain objective and subjective factors influence those perceptions is then explored.

\section{Determinants of job satisfaction}

One of the aspects of job satisfaction that has been studied the most is its relationship with wages. From a utilitarian standpoint, the two variables are expected to be positively correlated, and there is even an expectation that there will be a causative relationship whereby a higher wage will translate 
into a higher level of job satisfaction. The results do not always bear this out, however; for example, Clark and Oswald (1996) find just the opposite effect, while others (Bòria-Reverter, Crespi-Vallbona and Mascarilla-Miró, 2012) posit that some workers may be unhappy with their wage level but are nevertheless satisfied with their jobs in general. Yet Borra and Gómez (2012) and Farné and Vergara (2007) do find a positive impact. It may be that the outcome depends on other variables, such as being higher up or lower down in the income distribution. It is thought that what usually happens is that people who accept lower wages exhibit greater satisfaction because they value the fact that they are employed at all, regardless of the wage level. Card and others (2010) note that workers' responses may also be influenced by comparisons of relative wage levels and that these ratios are not linear, even though Clark, Nicolai and Westergård-Nielsen (2007) indicate that wage comparisons may have a positive effect on job satisfaction if a worker believes that this comparison provides a basis for an expectation of higher future levels of income.

Analyses of other objective factors yield differing results. With regard to working hours and the type of employment contract, Gamero (2003) finds that, in general, workers in Spain (particularly men) do not prefer part-time work and that they have no preference between private or public contracts, even though other studies, including that of De Vries and others (2015), point to a preference for publicsector jobs. Booth and Van Ours (2007) use a panel survey of British households and find differences between men and women, with no improvement in men's job satisfaction related to working hours, whereas there is an improvement in the case of women, who prefer part-time work.

Other determinants that have been studied include job stability (Clark and Postel-Vinay, 2009; Bòria-Reverter, Crespi-Vallbona and Mascarilla-Miró, 2012) and opportunities for promotion. The literature indicates that workers feel more unhappy when they have no upward mobility even if they are given a raise (Grund and Sliwka, 2007).

As noted by Bòria-Reverter, Crespi-Vallbona and Mascarilla-Miró (2012), in this field it is not enough to look at just wages or a worker's place in the corporate hierarchy; intrinsic variables such as opportunities for participation and a sense of being useful have to be taken into account as well. Organizational factors also play a part; for example, a correlation has been found between job satisfaction and a positive organizational environment (Juárez-Adauta, 2012) and good interpersonal relationships (Juárez-Adauta, 2012).

It has also been found that perceptions of job satisfaction or dissatisfaction are a response that may be influenced by personal characteristics, including sociodemographic factors such as age, marital status, sex and level of education. Some studies have reported that, contrary to what had been expected, women have greater job satisfaction than men (Clark, 1997), although the differential disappears among more highly educated young people. However, Sloane and Williams (2000) contend that women's greater satisfaction with their jobs is not associated with the types of jobs that they hold or their pay levels but instead is attributable to innate gender-related differences. Another possible explanation is that women have fewer employment opportunities and therefore are happier when they do manage to secure a job.

People who are less educated and have less job experience are thought to have fewer expectations of being able to find a different job, and their level of dissatisfaction with a lower level of achievement is therefore less; this is also true of wage levels (Belfield and Harris, 2002; Lévy-Garboua, Montmarquette and Simonnet, 2007).

Another variable that has been studied a great deal is union membership. Interestingly -and surprisingly - membership in a union is associated with less job satisfaction (Freeman, 1977). This may be because unionized workers have higher expectations by virtue of their union membership or because the people who belong to unions have a higher threshold of dissatisfaction and have 
joined a union in the hope of improving that perception. It has also been argued that unionization may have an endogenous selection effect whereby unionization could account for the level of job satisfaction and, at the same time, be accounted for by it (Bryson, Cappellari and Lucifora, 2004). Others have said that union membership is endogenous and lowers job satisfaction, but being in a union is entirely exogenous and has a positive impact on job satisfaction (Rodríguez-Gutiérrez and Prieto-Rodríguez, 2004).

It is also possible that the impact of these factors on job satisfaction differs from one location to the next, probably because of differences in surrounding conditions that influence people's perceptions of their own level of satisfaction. Pouliakas and Theodossiou (2010) have studied job satisfaction in various European countries and have found that the relationship between satisfaction and wage level differs across countries: in southern Europe, lower-paid workers are less satisfied than more highly paid workers are, but this does not hold true in northern Europe - presumably because of differences in job quality. Iglesias, Llorente and Dueñas (2010) studied the relationship between job quality and job satisfaction in Spain and found that job quality in Madrid during two different time periods was high, but workers were less satisfied with their jobs.

Studies have shown that large cities offer a number of attractions for workers because of the amenities that are available in those urban centres. The literature on these urban amenities is fairly recent and has helped to account for locational differences in wage levels (Macedo and Simões, 1998) and housing prices (Rocha and Magalhães, 2013). In Chile, the amenities available in urban centres have been characterized as an explanatory variable for migration flows to certain regions, particularly the Metropolitan Region (Aroca, Geoffrey and Paredes, 2001); a classification has even been developed for regions that are attractive as places to live and those that are attractive as places to work (Aroca and Atienza, 2008), and the hypothesis has been advanced that this variable may account for some portion of regional differences in the female labour participation rate (Ferrada and Zarzosa, 2010) and in long-distance commuting rates (Jamett and Paredes, 2013). While these matters will not be analysed in any depth here, they may provide a useful perspective on some of the results of this research.

The objective here will be to discern any geographically correlated differences in job satisfaction in Chile. It is suspected that inequalities will be found between the Metropolitan Region and the rest of Chile owing to the fact that wages are much higher in the Metropolitan Region and that the production matrix is much more spatially heterogeneous in that urban area, since, because it is so much more densely populated than the rest of the country, it offers an array of amenities and financial, administrative and consumer services, while the other regions of the country rely on economic activities that are based on natural resources and that are heavily dependent on external markets.

\section{Methodological aspects}

As noted earlier, this study will draw on first-hand information, i.e., survey respondents' assessments of their own employment situations. Causative models were used to evaluate the extent to which the levels of job satisfaction reported by wage earners in private companies in Chile are determined by objective factors, perceptions, place of residence or demographic aspects. In addition, using a coarsened exact matching impact assessment methodology, evidence was sought of possible differences in satisfaction levels between residents of the Metropolitan Region and of other areas of the country. SPSS (Statistical Package for the Social Sciences) software was used in arriving at the descriptive analysis, and the econometric estimates were calculated using Stata. 


\section{Data}

The data for this study were obtained from the first round of the National Survey on Employment, Work, Health and Quality of Life of Workers in Chile (ENETS), which was conducted in 2009-2010. It is the only survey of its kind in Chile; preliminary preparations for the second survey round are now under way (Ministry of Health, 2011).

This is a household survey, and the responses therefore do not necessarily correspond to the area where the respondents work. The respondents were persons over 15 years of age who had been employed during the 12-month period preceding the survey round. The survey sample (9,503 observations) was defined on the basis of the 2002 National Population and Housing Census.

The questionnaire was filled out by persons in all urban and rural regions of Chile with the exception of geographically remote areas. ${ }^{2}$ The survey sample was designed to permit the use of the extrapolation factors to ensure that it would be representative of the various regions. Using those factors, it was determined that the sample units are representative of 7,939,170 workers in Chile's 15 regions (Ministry of Health, 2011).

Of the total sample observations, 5,802 were for private-sector wage earners (other than domestic service workers) representing 4,532,274 people. The sample distribution by region, with and without weightings, is shown in table 1. At this level of disaggregation, however, the number of observations for some areas is very small; accordingly, for the purposes of this study's geographic analysis, the regions were grouped into seven zones based on criteria having to do with geographic proximity and production-sector features, as noted below.

Table 1

Sample, by region and zone (Number of people)

\begin{tabular}{|c|c|c|c|}
\hline Region & Sample & Weighted sample & Zone \\
\hline Arica & 256 & 42891 & \multirow{2}{*}{$\mathrm{Z1}$} \\
\hline Tarapacá & 216 & 74926 & \\
\hline Antofagasta & 320 & 164428 & \multirow{2}{*}{$\mathrm{Z} 2$} \\
\hline Atacama & 333 & 72532 & \\
\hline Coquimbo & 290 & 184691 & \multirow{2}{*}{ Z3 } \\
\hline Valparaíso & 594 & 445357 & \\
\hline Metropolitan & 1199 & 1973304 & Z4 \\
\hline O'Higgins & 375 & 280690 & \multirow{3}{*}{$\mathrm{Z} 5$} \\
\hline Maule & 318 & 231788 & \\
\hline Bío Bío & 532 & 498832 & \\
\hline Araucanía & 275 & 204647 & \multirow{3}{*}{ Z6 } \\
\hline Los Ríos & 288 & 83464 & \\
\hline Los Lagos & 280 & 208466 & \\
\hline Aysén & 246 & 24704 & \multirow{2}{*}{$\mathrm{Z7}$} \\
\hline Magallanes & 280 & 41554 & \\
\hline Total & 5802 & 4532274 & \\
\hline
\end{tabular}

Source: Prepared by the author, on the basis of data from the National Survey on Employment, Work, Health and Quality of Life of Workers in Chile.

2 These remote areas included: Ollagüe, Easter Island and Juan Fernández Island, Lago Verde, Guaitecas, Chile Chico, Villa O'Higgins, Tortel, Torres del Paine, Río Verde, Laguna Blanca, San Gregorio, Primavera, Timaukel, Cabo de Hornos and Antarctica. The communes of Chaitén, Futaleufú and Palena were not included either. 


\section{Dependent variables}

Job satisfaction is gauged on the basis of ENETS survey respondents' answers to the question: "How do you feel about your job?" Respondents were give seven options: very bad, bad, less than fair, fair, better than fair, good and very good. A total of 5,782 people answered this question, and their responses are calculated as being representative of 4,512,913 private-sector workers. The results for the study's target population are shown in figure 1.

Figure 1

Frequency of responses to the question "How do you feel about your job?"

(Percentages)

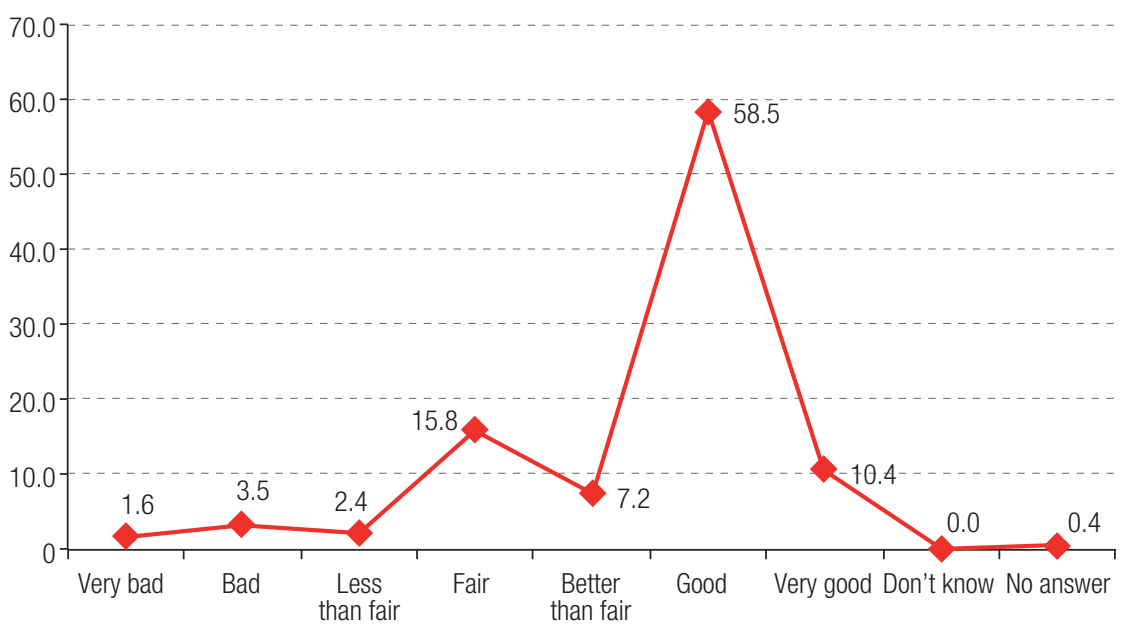

Source:Prepared by the author, on the basis of data from the National Survey on Employment, Work, Health and Quality of Life of Workers in Chile.

As is evident from the table, the workers' reported job satisfaction levels are quite high. This is yet another reason to try to determine what factors influence the perceptions of workers in the various geographical areas of the country, given the sharp wage differentials existing in Chile and the country's marked degree of spatial concentration.

\section{Methodology}

Given the distribution of the responses (see figure 1), this phenomenon is studied in two different ways, using a binary variable and a categorical variable, as follows:

- $\quad$ The binary SATIS2 variable takes a value of 1 when respondents report their level of job satisfaction as being very good or good and a value of 0 otherwise.

- $\quad$ The categorical SATIS3 variable is evaluated on the basis of three options: it takes a value of 1 when the response is "very bad", "bad", less than fair", "fair" or "better than fair"; a value of 2 if the response is "good"; and 3 if the response is "very good".

In the first case, a binary logit model is estimated; as will be seen later on, these estimates include geographical fixed effects which prove to be significant. In order to confirm the presence of such impacts, differences in job satisfaction between residents of the Metropolitan Region and residents in the rest of the country are estimated using an exact matching impact assessment methodology (Blackwell and others, 2009). The other model is a multinomial logit model (Greene, 1999). 


\section{(a) Binary logit model}

In this case the dichotomous dependent variable is SATIS2. Here, we evaluate how certain variables influence the probability that workers will be satisfied or very satisfied with their jobs. In this model, the coefficients are estimated using the maximum likelihood method, which can be written as follows (Greene, 1999):

$$
\hat{P}(S A T I S 2=1)=\frac{e^{X, \hat{\beta}}}{1+e^{X, \hat{\beta}}}=\wedge(\beta, X)
$$

where $\hat{\beta}$ is the vector of the estimated parameters and $X$ is the matrix of the explanatory variables.

The interpretation of the results is based on the estimated coefficients. The odds ratios for each explanatory variable are also calculated as:

$$
\Omega=\frac{P(S A T I S 2=1)}{P(S A T I S 2=0)}
$$

\section{(b) Exact matching method}

Although the preceding logit model included explanatory variables for place of residence, this method makes it possible to improve the comparison of job satisfaction for Metropolitan Region residents and persons living in other areas of Chile.

This method is primarily used to assess the impacts of public policies, but it is used here to compare groups of persons who share certain characteristics -in this case, groups of workers who gave similar answers for the $\mathrm{X}$-matrix variables defined in the preceding model. These are the control variables for the matching process. Therefore, in this exercise, the difference in job satisfaction is explained solely by the condition of being a worker who resides in the Metropolitan Region or who resides elsewhere in the country.

There are various matching techniques, but here we will use the exact matching method because, as indicated in the literature, it offers a number of advantages, including the fact that it fulfils the congruence principle, restricts the data matching to areas of common empirical support and is computationally efficient (Blackwell and others, 2009).

The procedure involves first conducting a matching exercise and then using a binary logit model to arrive at an estimate. The matching is done with the variables defined in the binary logit model.

In order to check that the matching process is satisfactory, the exact matching method is used to calculate the $\$ 1$ statistic, which represents the imbalance between the treated and untreated groups, whose value can vary between 0 and 1 . The idea is that, with the matching technique, the distributions should be as equal as possible, i.e., we should obtain a \1 statistic near 0 (lacus, King and Porro, 2012).

\section{(c) Multinomial logit model}

In order to see how the impact of the determinants changes when different levels of satisfaction are being analysed, an evaluation is conducted of the differences in the determinants for those who are very satisfied, those who are satisfied and those whose answers fall into one of the other categories; 
in other words, the responses are grouped into three categories (SATIS3). In this case, the dependent variable will take the first alternative (very bad, bad, less than fair, fair or more than fair) as a reference point (base category). Hence, $\mathrm{J}=0$ is the benchmark category, which conditions the interpretations of the coefficients estimated for the other options. This will indicate the impact on the likelihood that workers' levels of job satisfaction will increase to "satisfied" $(J=2)$ or "very satisfied" $(J=3)$. That is, for the benchmark:

$$
\hat{P}(S A T I S 3=j)=\frac{e^{X, \hat{\beta}}}{1+\sum_{j=1}^{j=2} e^{X, \hat{\beta}}}
$$

And the likelihood for the other options is:

$$
X \hat{\beta}=\alpha x+\rho x+\delta x
$$

where $\beta$ is the vector of the estimated parameters and $X$ is the matrix of the explanatory variables.

The parameters are estimated using the maximum likelihood method, and the estimators will then be those that maximize the likelihood of the observed sample. In order to interpret the model, the odds ratio is estimated, which allows for a clearer reading of the estimated models (Long and Freese, 2014).

\section{Explanatory variables}

Based on the definitions and empirical evidence that have been presented, variables are then selected for four types of characteristics. Then:

$$
X \hat{\beta}=\alpha x+\varphi x+\rho x+\delta x
$$

where $\alpha, \varphi, \rho$ and $\delta$ are the estimated parameters for the explanatory variables indicated in each case (demographic characteristics, objective employment factors, area of residence and worker perceptions, respectively). Each of these elements is analysed on the basis of the variables shown in table 2.

Initially, a larger set of possible determinants was analysed, in line with the preliminary literature review; however, before proceeding to calculate the estimates, each of those determinants was examined and a descriptive analysis was undertaken. Ultimately, the variables shown in table 2 were chosen for the rest of the study. Those that were excluded were ruled out either because the previous analysis showed that they were not relevant, because, in some cases, many responses had been omitted or because the number of positive responses was too low (as happened, for example, with the question about union membership), which makes it impossible to do cross comparisons at the zone level.

This same analysis yields the categories of explanatory variables. As will be noted, they are all dichotomous, since the responses corresponding to the variables of interest in the ENETS survey are given by category. In this case, different options were explored and, in the end, those shown in table 2 were selected. The only exception was for level of education, which was retained until, finally, based on the initial analysis, it was discarded. 


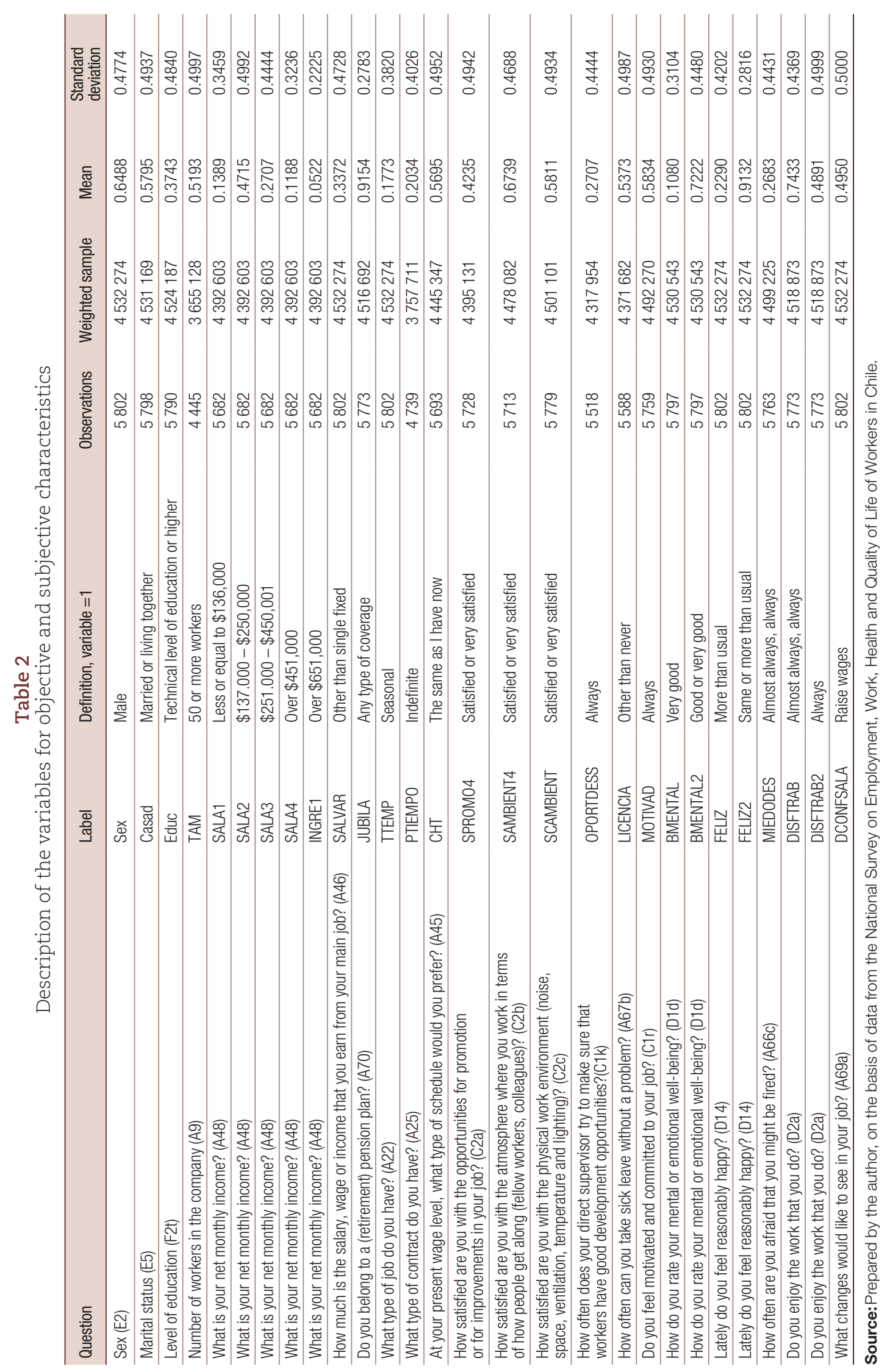




\section{Results}

Tables 3, 4 and 5 give the results of the logit regressions, the estimates with and without exact matching and the results obtained with the multinomial models, respectively. The analyses carried out in each case are described below.

\section{Logit model}

Three estimates were calculated: in the first, objective variables and respondents' characteristics were included; in the second, the zones were added; and, in the third, the subjective variables were added in.

As shown in table $3 \mathrm{~A}$, the likelihood that workers will be satisfied or very satisfied is significantly greater in the case of men, people who have a job that is not temporary and those who earn the most.

A majority of the workers are men (65\%) and only a third of workers have a higher education or at least a technical level of education (vocational secondary schooling or completed commercial training) (see table 2). Men have a $28 \%$ greater propensity to be satisfied than women do, while the level of education turned out not to be significant (see table 3A).

The most influential variable is the income derived from the main occupation. Around half of the respondents (47\%) indicated that they had a net monthly wage of between 137,000 pesos and 250,000 pesos (see table 2). The level of satisfaction of workers in this income bracket is significantly greater than it is for persons with lower wages, and the strength of the impact increases in tandem with the level of income (SALA3 and SALA4). On the other hand, the presence of temporary or seasonal contracts has a negative impact.

The ENETS tabulations indicate that $13 \%$ of wage earners in the private sector have a monthly income that is equal to or less than the legal minimum wage and that one fourth of them have incomes that are just slightly above the minimum wage. The Metropolitan Region is the zone in which average wages are the highest (see figure 2 ). ${ }^{3}$

The variables of marital status, company size (number of employees) pension plan coverage and fixed or variable wage were all evaluated as well, but, ultimately, they were not included because the results were not significant and did not contribute to the model.

When the variables for geographic zones (see table 3B) were incorporated, the resulting coefficient was consistently positive and significant, indicating that residence in a zone other than the Metropolitan Region (corresponding to the base zone in the estimate) has a positive influence on job satisfaction; the strength of that influence is lower in the northern zones of Chile, however. This finding is counterintuitive, inasmuch as higher wages have a positive effect on job satisfaction yet satisfaction levels are higher among people residing in zones other than the one where wages are the highest (Z4). The fact that the survey was conducted among households and that the responses came from one member of each household may have something to do with this result, since the respondents do not necessarily work in the zone where they live. This question will be explored further in the following section.

\footnotetext{
3 The survey questions concerned net income. The minimum wage in Chile in 2009 was 165,000 pesos and in 2010 it was 172,000 pesos; these are gross monthly figures. After subtracting pension contributions and insurance, they yield net figures of approximately 140,000 pesos and 146,000 pesos, respectively.
} 
Figure 2

Reported net wages, by zone

(Chilean pesos and percentages)

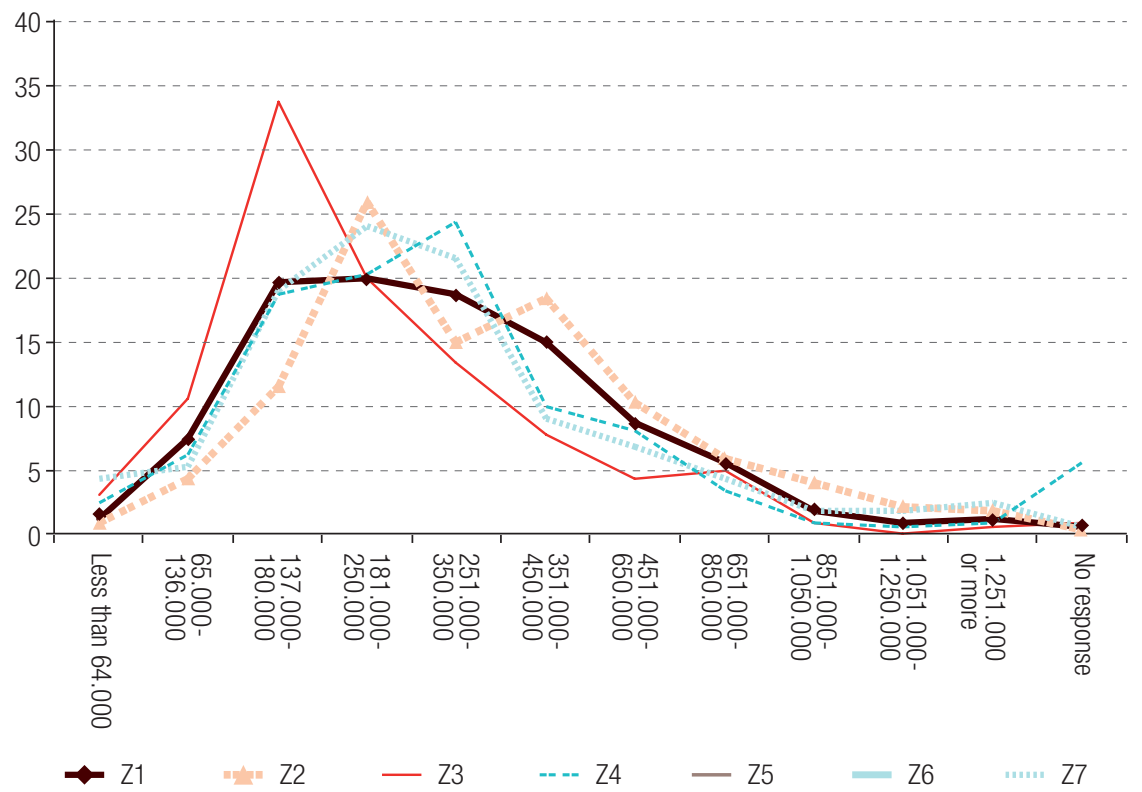

Source: Prepared by the author, on the basis of data from the National Survey on Employment, Work, Health and Quality of Life of Workers in Chile.

Table 3C shows the results obtained using the third model, which includes both objective and subjective variables. These results indicate that wage levels continue to be significant but that the variable for temporary versus more stable contracts does not.

The interesting point in this case is how important the subjective variables turn out to be. The factors having the biggest impact are whether the respondents feel good or very good mentally and emotionally (BMENTAL2) and whether they enjoy the work that they do (DISFTRAB2).

The likelihood of job satisfaction diminishes if the respondents are constantly afraid that they will be fired or laid off (MIEDODES) or if they are unhappy with their wage level (those who indicate that they would like a raise) (CONFSALA).

Other variables, such as satisfaction with promotion opportunities (SPROMO4), development opportunities (OPORTDESS), feeling reasonably happy (FELIZ2) and satisfaction with the work environment (SAMBIENT4), yield the results that were expected. It should be noted that the first two of these variables are associated with the management of the company, while the third has to do with subjective emotional factors and the fourth with the way the company is organized. The other variables did not have an impact on job satisfaction.

At the geographic level, the results indicate that the impact of the zone of residence disappears in the case of two of the zones ( $Z 2$ and $Z 7)$ but remains in the rest. 


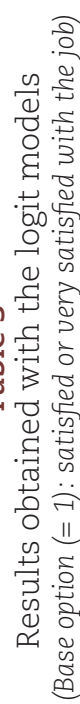

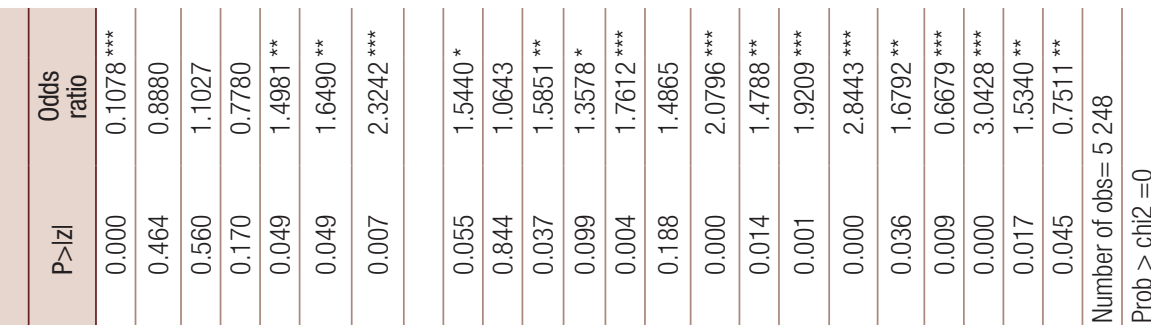

ن

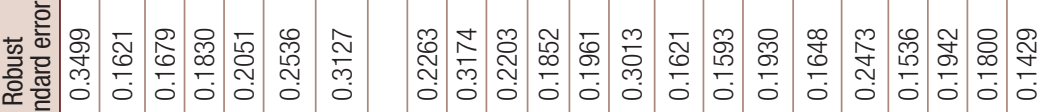

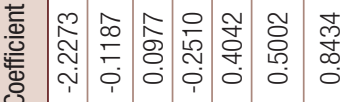

莳害究

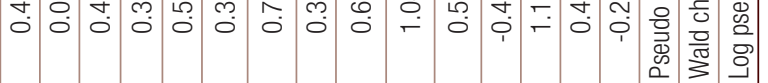

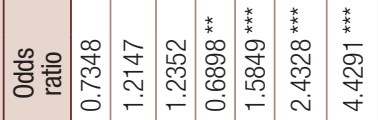

*

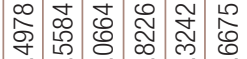

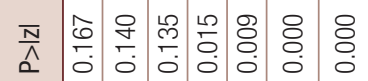

先

ळ

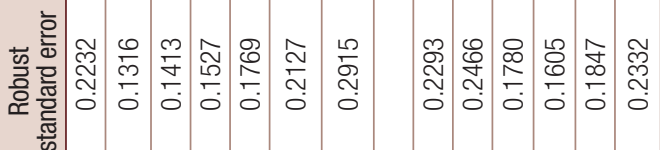

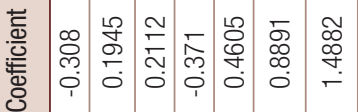

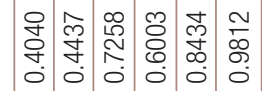

艿

每

$\therefore$ :

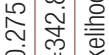

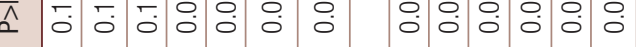

$\circlearrowleft$

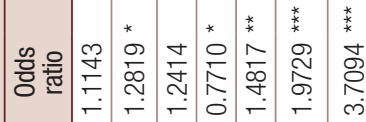

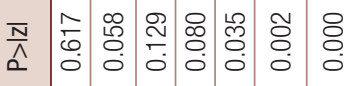

㐫

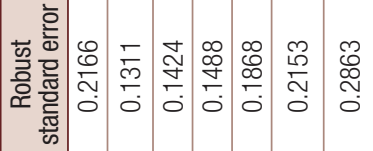

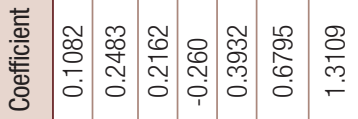

年

年

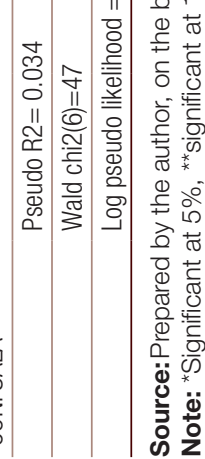




\section{Exact matching methodology}

The next step was to test these results to see how much of an impact residence in a zone other than the Metropolitan Region has on job satisfaction. As noted in the section on the methodology, the impact analysis technique known as exact matching was used for this purpose.

This evaluation was performed using two groups of subjects having all of the same characteristics except their zone of residence. In order to use the matching method, a common support for the two groups must be found. The variables used in this case were the determinants employed in the preceding logit estimate (see table $3 C$ ), which include both objective and subjective variables (sex, educ, TTEMP, SALA2, SALA3, SALA4, SPROMO4, SAMBIENT4, OPORTDESS, BMENTAL2, FELIZ2, MIEDODES, DISFTRAB, DISFTRAB2, CONFSALA).

This yields a matched base pair in which the one difference between the subjects is the place of residence. Thus, the likelihood that these persons will feel good or very good about their work was estimated using a logit model with a single explanatory variable that identifies the zone in which they live.

Comparisons were then made between the subjects in the Metropolitan Region and those living in all other regions of the country and then between the Metropolitan Region Zone (Z4) subjects and the subjects in each of the other zones; two types of estimates were calculated: estimates with and estimates without applying the exact matching method. The results are shown in table 4.

As may be seen from the table, the $\alpha 1$ indicator improves substantially in all cases. This indicates that the application of the exact matching methodology has produced two comparable groups, which makes it possible to improve the analysis. It has, however, also reduced the number of observations by between $54 \%$ and $61 \%$.

The estimates confirm that living in a zone other than the Metropolitan Region has a positive impact on job satisfaction. The analysis at the zone level yields the same result for four areas (Z3, Z5, Z6, Z7); a significant impact was not found in only two of the zones: Z1 and Z2.

Table 4

Estimates calculated with and without applying the exact matching method: impact of place of residence on the likelihood of job satisfaction

\begin{tabular}{|c|c|c|c|c|c|c|c|c|}
\hline & \multicolumn{7}{|c|}{ Impact of place of residence on the likelihood of job satisfaction (base zone = Z4) } \\
\hline & & ALL & Z1 & $\mathrm{Z2}$ & $\mathrm{Z3}$ & 25 & Z6 & $\mathrm{Z7}$ \\
\hline \multirow{7}{*}{$\begin{array}{l}\text { Before } \\
\text { matching }\end{array}$} & ¿1 statistic & 0.60113 & 0.713060 & 0.710915 & 0.648887 & 0.670845 & 0.687866 & 0.717844 \\
\hline & B & $\begin{array}{l}0.4407^{\star \star *} \\
(0.1368)\end{array}$ & $\begin{array}{l}0.5780^{* *} \\
(0.2497)\end{array}$ & $\begin{array}{l}0.5157^{\star *} \\
(0.2431)\end{array}$ & $\begin{array}{l}0.5571^{* * *} \\
(0.1917)\end{array}$ & $\begin{array}{c}0.2506 \\
(0.1596)\end{array}$ & $\begin{array}{l}0.5807^{* * *} \\
(0.1820)\end{array}$ & $\begin{array}{l}0.9323^{\star * *} \\
(0.2513)\end{array}$ \\
\hline & Constant & $\begin{array}{l}0.5351^{\text {***}} \\
(0.0664)\end{array}$ & $\begin{array}{l}0.5351^{\text {***}} \\
(0.1197)\end{array}$ & $\begin{array}{l}0.5351^{* * *} \\
(0.1197)\end{array}$ & $\begin{array}{l}0.5351^{\text {***}} \\
(0.1197)\end{array}$ & $\begin{array}{l}0.5351^{\text {***}} \\
(0.1197)\end{array}$ & $\begin{array}{l}0.5351^{\star \star *} \\
(0.1197)\end{array}$ & $\begin{array}{l}0.5351^{\text {***}} \\
(0.1197)\end{array}$ \\
\hline & Pseudo $\mathrm{R}^{2}$ & 0.0083 & 0.0029 & 0.0045 & 0.0096 & 0.0025 & 0.0089 & 0.0041 \\
\hline & Prob > chi2 & 0.0013 & 0.0029 & 0.0339 & 0.0037 & 0.1164 & 0.0014 & 0.0002 \\
\hline & Observ. SATIS2 $=0$ & 1401 & 480 & 506 & 576 & 709 & 571 & 449 \\
\hline & Observ. SATIS=1 & 3773 & 947 & 1125 & 1248 & 1417 & 1218 & 1028 \\
\hline \multirow{7}{*}{$\begin{array}{l}\text { After } \\
\text { matching }\end{array}$} & ¿1 statistic & $1.913 e-15$ & $2.88 \mathrm{e}-16$ & $5.89 e-16$ & $3.29 \mathrm{e}-16$ & $1.30 \mathrm{e}-15$ & $7.61 \mathrm{e}-17$ & $7.42 \mathrm{e}-16$ \\
\hline & B & $\begin{array}{l}0.3902^{\star * *} \\
(0.1035)\end{array}$ & $\begin{array}{c}0.3003 \\
(0.2045)\end{array}$ & $\begin{array}{c}0.2952 \\
(.2114)\end{array}$ & $\begin{array}{l}0.4196^{\star \star} \\
(0.1713)\end{array}$ & $\begin{array}{l}0.3171^{\star *} \\
(0.1462)\end{array}$ & $\begin{array}{l}0.4751^{\star \star \star} \\
(0.1705)\end{array}$ & $\begin{array}{l}0.8197^{\star \star \star} \\
(0.2695)\end{array}$ \\
\hline & Constant & $\begin{array}{l}1.1511^{\text {*** }} \\
(0.057)\end{array}$ & $\begin{array}{c}1.010^{\star \star \star} \\
(0.1240)\end{array}$ & $\begin{array}{l}1.522^{\star \star \star} \\
(0.1374)\end{array}$ & 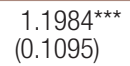 & $\begin{array}{l}0^{0.8739} \\
(0.1012)\end{array}$ & $\begin{array}{l}1.040^{\star \star \star} \\
(0.1123)\end{array}$ & $\begin{array}{c}1.582^{\star \star \star} \\
(0.1520)\end{array}$ \\
\hline & Pseudo $\mathrm{R}^{2}$ & 0.0052 & 0.0035 & 0.0033 & 0.0069 & 0.0042 & 0.0091 & 0.0225 \\
\hline & Prob > chi2 & 0.0001 & 0.1391 & 0.1606 & 0.0135 & 0.0298 & 0.0050 & 0.0016 \\
\hline & Observ. SATIS2 $=0$ & 737 & 332 & 360 & 468 & 470 & 411 & 306 \\
\hline & Observ. SATIS=1 & 2143 & 226 & 322 & 417 & 502 & 411 & 265 \\
\hline
\end{tabular}

Source: Prepared by the author, on the basis of data from the National Survey on Employment, Work, Health and Quality of Life of Workers in Chile.

Note: ${ }^{\star}$ Significant at $5 \%,{ }^{\star \star}$ significant at $1 \%,{ }^{\star \star \star}$ significant at $10 \%$. Robust standard deviations are shown in brackets. 


\section{Multinomial model}

This model will be used to look at possible differences in impact by level of satisfaction, i.e., to calculate the probabilities that subjects will feel good or very good about their job, in different categories, as stated in equations (3) and (4).

Three models are estimated, as shown in tables 5A, 5B and 5C. In the first, it can be seen that the subjects' propensity to be very satisfied with their jobs is greater than the other options if they have a high level of education; in that latter category, the person's sex ceases to be significant. In addition, the impact of higher wages is greater than in option 3 (feel very good about their job).

In the second model, when the residence variables are incorporated (see table 5B), effects similar to those found with the binary logit model are observed, although zones 1, 2 and 5 are not significant.

Table $5 \mathrm{C}$ shows the model with objective and subjective variables but without incorporating place of residence. What is interesting here is the difference in the impact of the subjective variables across categories. For example, satisfaction with working hours (CHT) has a significant and positive impact on the likelihood of feeling very good about one's job, but not in the next category down (feeling good). Subjects with temporary contracts (TTEMP) are less likely to feel very good about their job.

Some subjective factors have an effect in both cases but their impact is greater for the third option (feeling very satisfied). In this case, the variables are satisfaction with the work environment (SAMBIENT4), development opportunities (OPORTDESS) and always enjoys work (DISFTRAB).

However, the variables of fear of being fired or laid off, satisfaction with the existing wage and feeling good the same usual as or more than usual only influence the propensity to be satisfied. It is possible that, in order to be very satisfied, the expectations to be met are higher, as evidenced by the DISFTRAB and DISFTRAB2 variables. In this case, always enjoying one's job has a positive impact in both cases, whereas enjoying one's job always or almost always has a positive effect only on feeling good about one's job (category 2). In turn, those who feel good or very good mentally and emotionally (BMENTAL and BMENTAL2) are 2.2 times and 10.6 times more likely, respectively, to feel very good about their job.

This analysis shows how important subjective variables associated with human resources management and the organizational environment are in determining the level of job satisfaction. The results are compelling: employees value these types of conditions even more than they value objective working conditions. This finding may have important implications for organizational management and public policy.

Table 5

Results obtained with multinomial models

(Base option (=1): dissatisfied with the job)

\begin{tabular}{|c|c|c|c|c|c|c|c|c|c|}
\hline \multirow{2}{*}{\multicolumn{2}{|c|}{ SATIS3 }} & \multicolumn{4}{|c|}{ Option 2: feels good (satisfied) } & \multicolumn{4}{|c|}{ Option 3: feels very good (very satisfied) } \\
\hline & & Coefficient & $\begin{array}{l}\text { Robust } \\
\text { standard } \\
\text { error }\end{array}$ & $P>|z|$ & $\begin{array}{l}\text { Odds } \\
\text { ratio }\end{array}$ & Coefficient & $\begin{array}{l}\text { Robust } \\
\text { standard } \\
\text { error }\end{array}$ & $P>|z|$ & $\begin{array}{l}\text { Odds } \\
\text { ratio }\end{array}$ \\
\hline \multirow[t]{6}{*}{$5 \mathrm{~A}$} & Sex & 0.3038 & 0.1336 & 0.023 & 1.3551 ** & -0.1161 & 0.2217 & 0.601 & 0.8904 \\
\hline & Educ & 0.1583 & 0.1440 & 0.272 & 1.1715 & 0.6900 & 0.2497 & 0.006 & $1.9937^{\star \star \star}$ \\
\hline & SALA2 & 0.4112 & 0.1792 & 0.022 & 1.5086 ** & 0.7928 & 0.3019 & 0.009 & 2.2096 *** \\
\hline & SALA3 & 0.6833 & 0.2077 & 0.001 & 1.9804 *** & 1.3884 & 0.3571 & 0.000 & $4.0086^{\star \star \star}$ \\
\hline & SALA4 & 1.3090 & 0.2844 & 0.000 & $3.7026^{* \star *}$ & 2.0669 & 0.4035 & 0.000 & 7.9002 *** \\
\hline & Constant & -0.1107 & 0.1911 & 0.562 & 0.8952 & -2.4200 & 0.3193 & 0.000 & 0.0889 *** \\
\hline
\end{tabular}

Number of observations $=5653$; Wald chi2(10)=64,4; Prob $>$ chi2=0; Log pseudo likelihood $=0,0315$ 
Table 5 (concluded)

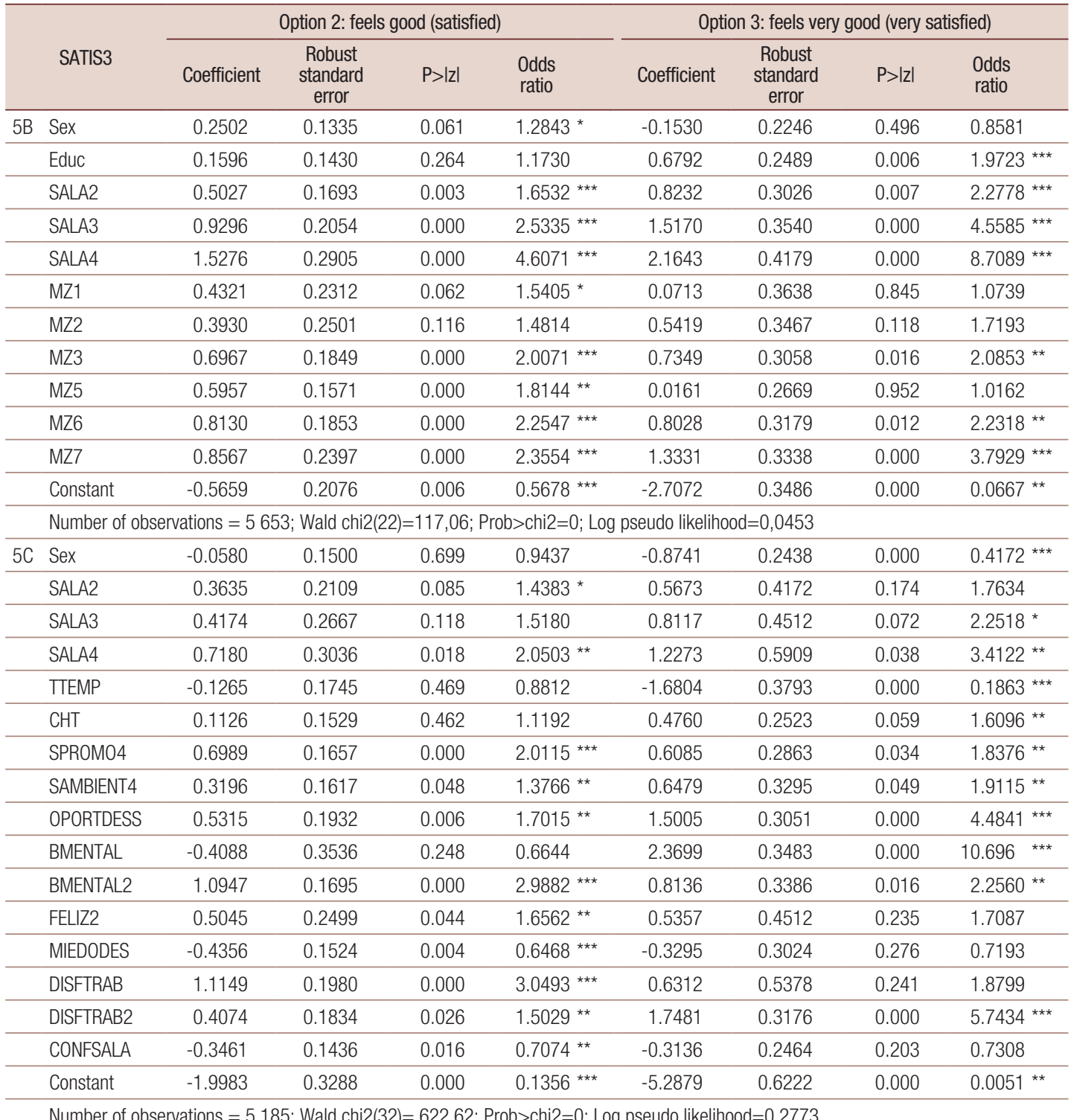

Number of observations $=5$ 185; Wald chi2(32)=622,62; Prob $>$ chi2=0; Log pseudo likelihood=0,2773

Source: Prepared by the author, on the basis of data from the National Survey on Employment, Work, Health and Quality of Life of Workers in Chile.

Note: ${ }^{*}$ Significant at $5 \%,{ }^{* \star}$ significant at $1 \%,{ }^{\star \star *}$ significant at $10 \%$.

\section{Conclusions}

In line with the initial objective of this study, the level of job satisfaction of private-sector wage earners in Chile has been analysed by evaluating the impact of a number of different variables and by gauging differences in perceived job satisfaction on the part of persons residing in the Metropolitan Region and in other zones of Chile. This research has been undertaken with the intention of contributing to the understanding of this subject in the country, since very few studies on the topic have taken geographical factors into account.

The research was based on ENETS survey data for 2009-2010; this was the first survey that included such a wide range of subjective variables and that was regionally representative. 
The international literature provides a variety of findings regarding the impact of wage levels on job satisfaction. The results of this study indicate that wages levels definitely have a positive and significant impact, and they are consistent inasmuch as, the higher the wage, the greater this effect is; when the dependent variable was analysed in the three-category model, the coefficient was the highest in category 3 (feel very good about their job) (multinomial model).

The results of this analysis regarding subjective variables are quite interesting, inasmuch as they demonstrate that these variables have a greater impact than the objective variables do. In fact, of all the factors that were initially considered, the final two models ( $3 \mathrm{C}$ and $5 \mathrm{C}$ ) are composed primarily of subjective factors (perceptions).

The variables associated with job quality, such as social security and type of contract, were not significant; what is more, even when the wage level is the only objective variable that is left, when subjective determinants are added in, they are more significant. This finding is an important one, since the main thrust of public policy in this area in Chile is to achieve a certain minimum level in terms of job quality, whereas employees are, in all likelihood, placing greater value on perceived (subjective) conditions relating to human resources and organizational management.

In addition, when job satisfaction is analysed on the basis of three different categories, the differences in the influence exerted by subjective variables are notable.

However, the propensity to feel good about one's job is greater in areas other than the Metropolitan Region and, when the results are analysed by zone, only zones 1 and 2 in the far north cease to be significant. This finding seems to be counterintuitive, since wages are higher in the Metropolitan Region in relative terms and since that region also presumably offers greater amenities. The reasons for this result have not been analysed in this study but should, of course, be explored. In the meantime, a few possible explanations will be examined on the basis of some degree of intuition.

First of all, one hypothesis, based on an extrapolation of the material provided in the literature, is that, while wages are lower in other regions, particularly those subsumed under zones 3, 4, 5 and 6, perhaps the residents of those areas are more satisfied simply by the fact that they have a job at all; it is possible, then, that their job satisfaction threshold is lower.

Another reason might be that, since subjective variables (perceptions) are so influential, the impact of these factors, in combination with those of other location-related conditions (cultural factors, social circles, family ties, among others), outweigh the importance of wage levels. This could also account for Chile's low labour mobility.

Finally, it may be that wages exhibit endogenous behaviour as a reflection of dual causality. In other words, job satisfaction could be determining employees' wage levels; if this is the case, it would corroborate the importance of perceptions and, following on with the above line of reasoning, would explain the positive effect of living in a zone other than the Metropolitan Region, although this result would be somewhat contradictory, given the marked concentration of the population in that region.

The results to date indicate, on the one hand, that this subject area should be approached from a geographic perspective and that possible differences between regions should be explored. This, in turn, points to the importance of using decentralized public policy tools. The information provided by this study on the influence exerted by objective and subjective variables affords relevant inputs in terms of both public policymaking and business administration, since it underscores the importance of human resources management and organizational arrangements dealing with the work environment in terms of employees' job satisfaction. An interesting question -that will remain unanswered here - is whether or not the "new management" approach will have differing effects in different geographical areas.

Finally, this study points to the need for an updated survey design that will include variables that capture people's perceptions of job quality, performance, work environment and job satisfaction and that will thus make it possible to verify the temporal consistency of these results. 


\section{Bibliography}

Aroca, P. and M. Atienza (2008), "La conmutación regional en Chile y su impacto en la Región de Antofagasta", EURE, vol. 34, No. 102, Santiago, Catholic University of Chile.

Aroca, P., J. D. Geoffrey and J. Paredes (2001), "Migracion interregional y el mercado laboral en Chile: 1977-82 y 1987-92", Cuadernos de Economía, vol. 38, No. 115, Santiago, Catholic University of Chile.

Becker, G. (1964), Human Capital, Chicago, The University of Chicago Press.

Belfield, C. and R. Harris (2002), "How well do theories of job matching explain variations in job satisfaction across education levels? Evidence for UK graduates", Applied Economics, vol. 34, No. 5, Taylor \& Francis.

Blackwell, M. and others (2009), "CEM: coarsened exact matching in Stata", The Stata Journal, vol. 9, No. 4.

Booth, A. and J. Van Ours (2007), "Job satisfaction and family happiness: the part-time work puzzle", Working Paper Series, No. 100, Melbourne, University of Melbourne.

Bòria-Reverter, S., M. Crespi-Vallbona and O. Mascarilla-Miró (2012), "Variables determinantes de la satisfacción laboral en España", Cuadernos de Economía, vol. 35, No. 97, Elsevier.

Borra, C. and F. Gómez (2012), "Satisfacción laboral y salario: ¿compensa la renta laboral las condiciones no monetarias del trabajo?, Revista de Economía Aplicada, vol. 20, No. 3, University of Zaragoza.

Bryson, A., L. Cappellari and C. Lucifora (2004), "Does union membership really reduce job satisfaction?", British Journal of Industrial Relations, vol. 42, No. 3, Wiley.

Card, D. and others (2010), "Inequality at work: the effect of peer salaries on job satisfaction", NBER Working Paper, No. 16396, Cambridge, Massachusetts, National Bureau of Economic Research (NBER).

Chiavenato, I. (2006), Introducción a la teoría general de la administración, McGraw-Hill.

Clark, A. (1997), "Job satisfaction and gender: why are women so happy at work?", Labour Economics, vol. 4, No. 4, Amsterdam, Elsevier.

Clark, A. and A. Oswald (1996), "Satisfaction and comparison income", Journal of Public Economics, vol. 61, No. 3, Amsterdam, Elsevier.

Clark, A. and F. Postel-Vinay (2009), "Job security and job protection", Oxford Economic Papers, vol. 61, No. 2, Oxford University Press.

Clark, A., K. Nicolai and N. Westergård-Nielsen (2007), "Job satisfaction and co-worker wages: status or signal?", IZA Discussion Paper, No. 3073.

De Vries, W. and others (2015), "Conclusiones a contrapelo: la aportación de distintas carreras universitarias a la satisfacción en el empleo", Revista de la Educación Superior, vol. 37, No. 146, National Association of Universities and Higher Education Institutions.

Farné, S. (2012), La calidad del empleo en América Latina a principios del siglo XXI, Bogota, Universidad Externado de Colombia. (2003), Estudio sobre la calidad de empleo en Colombia, International Labour Organization.

Farné, S. and A. Vergara (2007), "Calidad del empleo: ¿qué tan satisfechos están los colombianos con su trabajo?", Cuadernos de Trabajo, No. 8, Bogotá, Universidad Externado de Colombia.

Ferrada, L. M. and P. Zarzosa (2010), "Diferencias regionales en la participación laboral femenina en Chile", Cuadernos de Economía, vol. 47, No. 136, Santiago, Catholic University of Chile.

Freeman, R. (1977), "Job satisfaction as an economic variable", NBER Working Paper, No. 225, Cambridge, Massachusetts, National Bureau of Economic Research (NBER).

Gamero, C. (2003), "Análisis por género de la relación entre satisfacción laboral and tipo de contrato en España", Anales de Economía Aplicada 2007, Spanish Association of Applied Economics.

Greene, W. (1999), Análisis econométrico, Madrid, Prentice Hall.

Grund, C. and D. Sliwka (2007), "Reference-dependent preferences and the impact of wage increases on job satisfaction: theory and evidence", Journal of Institutional and Theoretical Economics (JITE), vol. 163, No. 2, Mohr Siebeck.

Herzberg, F. (1962), "Basic needs and satisfactions of individuals", Industrial Relations Monograph, No. 21. Herzberg, F., B. Mausner and B. Sryderman (1959), The Motivation to Work, New York, John Wiley and Sons.

lacus, S., G. King and G. Porro (2012), "Causal inference without balance checking: coarsened exact matching", Political Analysis, vol. 20, No. 1, Cambridge, Cambridge University Press.

Iglesias, C., R. Llorente and D. Dueñas (2010), "Calidad del empleo and satisfacción laboral”, Investigaciones Regionales, No. 19, Spanish Association of Regional Science.

ILO (International Labour Organization) (1999), "Decent work", Report of the Director-General, 87th session of the International Labour Conference, Geneva. 
INE (National Institute of Statistics) (n/d) [online] http://www.ine.cl/canales/chile_estadistico/mercado_del_ trabajo/empleo/series_estadisticas/nuevas_empalmadas/series_fecha.php.

_ (n/d) [online] http://www.ine.cl/canales/chile_estadistico/mercado_del_trabajo/remuneraciones/anuarios_ estadisticos/anuarios_estadisticos.php.

Jamett, I. and D. Paredes (2013), "Conmutación de larga distancia en Chile: estimando el premio por trabajar muy lejos de casa", Estudios de Economía, vol. 40, No. 2, Santiago, University of Chile.

Juárez-Adauta, S. (2012), "Clima organizacional y satisfacción laboral", Revista Médica del Instituto Mexicano del Seguro Social, vol. 50, No. 3, Mexico City, Mexican Social Security Institute.

Lévy-Garboua, L., C. Montmarquette and V. Simonnet (2007), "Job satisfaction and quits", Labour Economics, vol. 14, No. 2, Amsterdam, Elsevier.

Long, J. and J. Freese (2014), Regression Models for Categorical Dependent Variables Using Stata, Stata Press.

Macedo, P. and R. Simões (1998), "Amenidades urbanas e correlação espacial: uma analise intra-urbana para BH (MG)", Revista Brasileira de Economia, vol. 4, No. 52, Getulio Vargas Foundation.

McGregor, D. (1981), El aspecto humano de las empresas, Mexico City, Diana.

Mincer, J. (1958), "Investment in human capital and personal income distribution", Journal of Political Economy, vol. 66, No. 4, Chicago, The University of Chicago Press.

MINSAL (Ministry of Health) (2011), "Primera encuesta nacional de empleo, trabajo, salud y calidad de vida de los trabajadores y trabajadoras en chile (ENETS 2009-2010)" [online] http://epi.minsal.cl/epi/Onotransmisibles/ ENETS/INTERINSTITUCIONAL_BAJA.pdf.

_(n/d), "Diseño conceptual and metodológico" [online] http://epi.minsal.cl/wp-content/uploads/2012/07/ Resumen_Ejecutivo_ENETS_Final.pdf.

Narbona, K. (2012), "La producción de compromiso en la empresa flexible", Santiago, University of Chile [online] http://repositorio.uchile.cl/handle/2250/116785.

Olarte, M. (2011), Los determinantes de la satisfacción laboral: una revisión teórica and empírica, Bogota, Universidad Jorge Tadeo Lozano.

Pouliakas, K. and I. Theodossiou (2010), "Differences in the job satisfaction of high-paid and low-paid workers across Europe", International Labour Review, vol. 129, No. 1, International Labour Organization.

Rocha, R. and A. Magalhães (2013), "Valoração das amenidades urbanas: uma estimação a partir dos diferenciais salariais e do custo de habitação para as regiões metropolitanas brasileiras", Revista de Economia Contemporanea, vol. 17, No. 1, Rio de Janeiro, Institute of Economics of the Federal University of Rio de Janeiro.

Rodríguez-Gutiérrez, C. and J. Prieto-Rodríguez (2004), "Efecto de la afiliación sindical sobre la satisfacción laboral de los trabajadores en el caso español” [online] http://aeet-aede.ulpgc.es/Descargas/Sesion1Sala2/ Rodriguez-Prieto.pdf.

Sehnbruch, K. (2012), "La calidad del empleo en Chile: teoría y medición”, La calidad del empleo en América Latina a principios del siglo XXI, S. Farné (comp.), Bogota, Universidad Externado de Colombia.

(2008), "From the quantity to the quality of employment: an application of the capability approach to the Chilean labour market", The Capability Approach: Concepts, Measures and Applications, F. Comim, M. Qizilbash and S. Alkire, New York, Cambridge University Press.

Sen, A. (1999), Development as Freedom, Oxford, Oxford University Press.

Sloane, P. J. and H. Williams (2000), "Job satisfaction, comparison earnings, and gender", Labour, vol. 14, No. 3, Wiley.

Somarriba, N. and others (2010), "La calidad del trabajo en la Unión Europea", Estudios de Economía Aplicada, vol. 28, No. 3.

Stephen, R. and J. Timothy (2013), Comportamiento organizacional, Pearson. 